\title{
Van Gölü Havzası Doğu ve Kuzey Bölgesindeki Killerin Standart ve Modifiye Proktor Özelliklerinin Belirlenmesi
}

\author{
Ali ÖZVAN"1, Onur SARAN², Murat MUVAFIK ${ }^{2}$ \\ ${ }^{1}$ Van Yüzüncü Yıl Üniversitesi, Mühendislik Fakültesi, Jeoloji Mühendisliği Bölümü, Van \\ ${ }^{2}$ Van Yüzüncü Yıl Üniversitesi, Mühendislik Fakültesi, İnşaat Mühendisliği Bölümü, Van
}

Geliş tarihi: 25.06.2020 Kabul tarihi: 30.07 .2020

\section{$\ddot{O} z$}

$\mathrm{Bu}$ çalışmada kompaksiyonun önemli bir parametresi olan sıkıştırma enerjisinin, zemine farklı miktarlarda uygulanması durumunda zeminin mühendislik özelliklerindeki değişiklikler araştırılmıştır. Çalışma için Van Gölü'nün doğu ve kuzeyindeki farklı konumlardan elde edilen bozulmuş kil örnekleri kullanılmıştır. Tüm zeminler öncelikle Proktor deneylerine tabi tutularak zeminlerin optimum su içeriği $\left(\omega_{\text {opt }}\right)$ ve maksimum kuru birim hacim ağırlık $\left(\gamma_{\mathrm{k}-\mathrm{max}}\right)$ değerleri belirlenmiştir. İkinci aşamada, kompaksiyon deneyinden alınan numuneler konsolidasyon deneyine tabi tutulmuştur. Konsolidasyon sonuçlarına bakıldığında zemine uygulanan kompaksiyon enerjisi arttıkça zeminin kuru birim hacim ağırlığının ve ön konsolidasyon basıncının arttı̆̆ı, optimum su içeriğinin ve boşluk oranının azaldı̆̆ 1 belirlenmiştir. Bölgeden alınan örneklerin proktor değerleri incelendiğinde, Çaldıran bölgesi hariç tüm kil örneklerinin dolguda kullanılabileceği belirlenmiştir. Ayrıca, bu killerin Plastik Limit değerleri ile Proktor sıkışma parametreleri arasında yapılan korelasyonlarda yüksek belirleme katsayısı $\left(\mathrm{R}^{2}>0.90\right)$ elde edilmiştir.

Anahtar Kelimeler: Kil, Proktor deneyi, Kompaksiyon enerjisi, Van

\section{Determination of Standard and Modified Proctor Properties of Clay Soils in Eastern and Northern of Van Lake}

\begin{abstract}
In this study, the changes in the engineering properties of the soil in case of application of compaction energy, which is an important parameters of the compaction, in different amounts have been investigated. For the study, disturbed clay samples obtained from different locations in eastern and northern of Van Lake, have been used. Firstly, all clay soils were subjected to Proctor experiments and optimum water content $\left(\omega_{\text {opt }}\right)$ and maximum dry unit volume weight $\left(\gamma_{\mathrm{k} \text {-max }}\right)$ values were determined. In the second stage,
\end{abstract}

*Sorumlu yazar (Corresponding author): Ali ÖZVAN, aozvan@yyu.edu.tr 
samples taken from the compaction test were subjected to consolidation test. Considering the results of consolidation, it was determined that as the compaction energy applied to the soil increases, the dry unit volume weight and pre-consolidation pressure increase while the optimum water content and void ratio decrease. When the proctor values of the samples taken from the region are analyzed, it was determined that all clay samples can be used in the filling except the Çaldıran region. In addition, high correlation coefficient was obtained in the correlations between the Plastic Limit values and the Proctor compaction parameters of these clays.

Keywords: Clay, Proctor compaction test, Compaction energy, Van

\section{GíRiș}

Mekanik stabilizasyon yöntemlerinden biri olan kompaksiyon, mekanik enerji uygulanması yoluyla yoğunluğun arttırılması işlemidir [1]. Sıkıştırılmış zeminler cinslerine ve kompaksiyon yöntemlerine bağlı olarak farklı özelliklere sahiptirler ve projelendirme aşamalarında zeminlerin sıkıştırılmış haldeki özellikleri önemli bir faktördür. Burada bahsedilen özellikler geçirimlilik (permeabilite), sıkışabilirlik yeteneği, gerilme-deformasyon ilişkisi ve kayma direncidir.

Zeminlerin geçirimliliği ile boşluk oranları arasındaki ilişki göz önüne alınacak olursa, kuru birim hacim ağırlığın artması durumunda, porozitenin azalması ve buna bağlı olarak geçirimliliğin de azalması beklenir [2]. En büyük kuru birim hacim ağırlığın değişimi kompaksiyon deneyi ile belirlenebilir. Kompaksiyon deney verileri kullanılarak çizilen kompaksiyon eğrileri optimumdan kuru, optimum ve optimumdan islak olmak üzere üç kısımdan oluşur (Şekil 1).Lambe [3], optimumdan kuru bölgede sıkıştırılan zemindeki su muhtevası arttıkça zeminin geçirimliliğinin azaldığını, optimum su muhtevasında minimum olduğunu, optimumdan sslak bölgede ise başlangıçta azalıp daha sonra arttığını gözlemlemiştir (Şekil 1). Ayrıca, kompaksiyon deneyinde artan su içeriğine bağlı olarak kilin yapısı incelendiğinde; optimumdan kuru bölgede parçacıklar arasındaki kenar-kenar temasları, optimum su içeriğinin yakınında esas olarak kenar-yüzey ve yüzey-yüzey temasları haline gelmekte ve su içeriği arttıkça yüzey-yüzey temas sayıları artmaktadır [5].

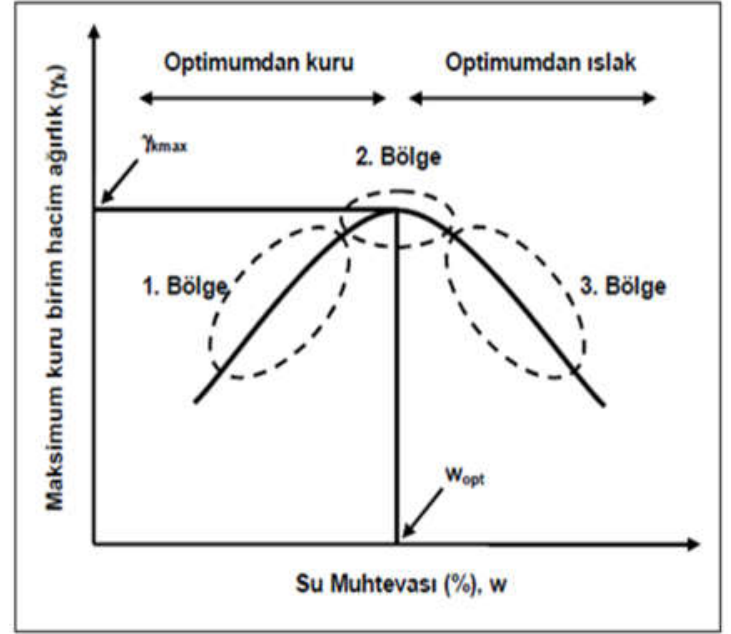

Şekil 1. Sıkıştırılmış bir zeminde kuru birim hacim ağırlık $\left(\gamma_{\mathrm{k}}\right)$ - su muhtevası $(\omega)$ ilişkisi

Yüksek sıkıştırma enerjisi de zeminlerde kuru yoğunluğun artmasını ve boşluk oranının azalmasını sağlar. Optimumdan 1slak bölgede, yüksek enerji ile sıkıştırılan zeminlerde tane dizilimlerinin paralel olmasiyla birlikte tane düzlemine dik doğrultudaki geçirimlilik azalırken diğer yönde önemli bir değişim yaşanmamaktadır [2-4].

Sıkıştırılmış kilde; sıkışabilirlik, zemin yapısının ve su muhtevasının belirgin olarak etkilendiği bir başka özelliktir. Lambe [3], aynı kuru birim hacim ağırlık değerine sahip optimumdan kuru bölgede sıkıştırılan kilin sıkışabilirliğinin, optimumdan ıslak bölgede sıkıştırılan kilin sıkışabilirliğinden daha düşük olduğunu ortaya koymuştur. Şekil 2a'da düşük basınç uygulanan, Şekil 2b'de ise yüksek basınç uygulanan, optimumdan kuru ve 
optimumdan ıslak bölgelerde sıkıştırılmış killerin bir boyutlu konsolidasyon özellikleri verilmiştir.

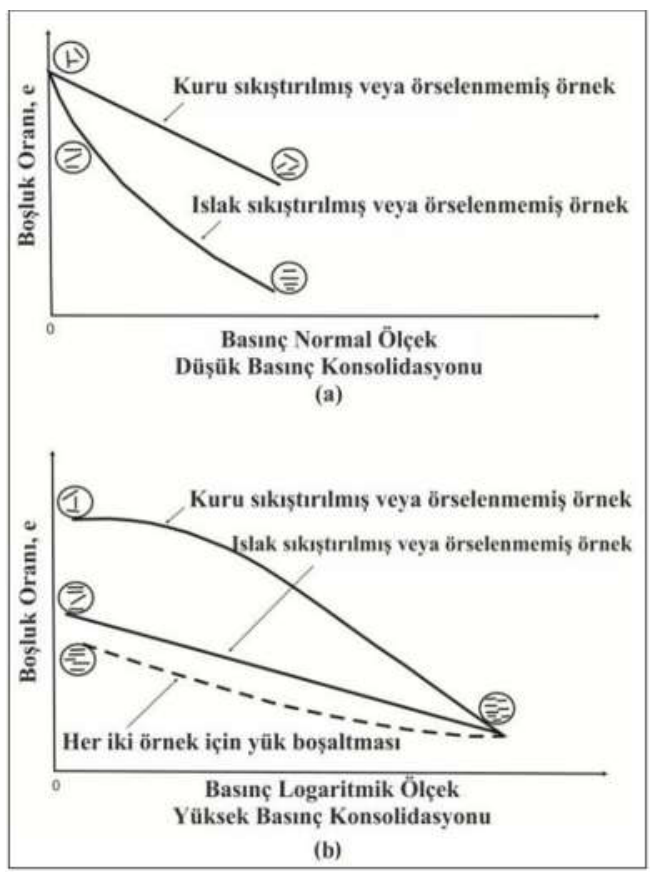

Şekil 2. Sıkıştırmanın bir boyutlu konsolidasyona etkisi, a) Düşük basınçta, b) Yüksek basınçta [4]

Şekillerden görüldüğü gibi, yüksek basınç uygulandığ 1 durumda, optimumdan kuru bölgede sıkıştırılan kilin sıkışabilirliği optimumdan ıslak bölgede sıkıştırılandan daha yüksektir. Düşük basınç uygulandığı durumda ise tam tersi durum söz konusudur. Yani bu durumda, optimumdan sslak bölgede sıkıştırılan kilin sıkışabilirliği optimumdan kuru bölgede sıkıştırılandan daha yüksektir [3].

$\mathrm{Bu}$ çalışmada, Ateş 2010'da [6] fiziksel ve mineralojik özellikleri verilen killerin farklı sıkışma enerjisine bağlı olarak kompaksiyon ve konsolidasyon özelliklerinin nasıl değiştiği ve elde edilen değerler ile bu malzemelerin Van Gölü etrafinda yapımı planlanan ve devam eden mühendislik yapılarında kullanılabilirliğinin ortaya çıkarılması amaçlanmıştır. Ayrıca, bu killerin indeks özellikleri ile kompaksiyon değerleri arasında bir ilişkinin varlığının araştırılması da çalışmanın bir diğer amacı olarak hedeflenmiştir.

\section{MATERYAL VE METOT}

\subsection{Materyal}

Bu çalışmada, Van Gölü doğu ve kuzeyinde Ateş 2010 [6] tarafindan kil özellikleri belirlenmiş koordinatlardan numuneler alınmıştır. Çalışma kapsamında, verilen koordinatlar veya yakın çevresinden örselenmiş zemin örneği alınarak laboratuvara getirilmiştir. Ateş 2010'da [6] kil olarak tanımlanmış zeminlerin alındığı koordinatlar Çizelge 1'de verilmiştir.

Çizelge 1. Çalışma kapsamında kullanılan killerin alındığı yerler ve ondalık derece cinsinden konumları

\begin{tabular}{|c|c|c|c|}
\hline \multirow{2}{*}{ Numune Kodu } & \multirow{2}{*}{ Alındığı Bölge } & \multicolumn{2}{|c|}{ Konum } \\
\hline & & Enlem & Boylam \\
\hline GR-1 & Gürpınar-Van Karayolu & $38,348317^{\circ}$ & $43,421102^{\circ}$ \\
\hline GR-2 & Gürpınar Karayolu üzeri & $38,331243^{\circ}$ & $43,240738^{\circ}$ \\
\hline GR-3 & Gürpınar Karayolu üzeri & $38,328577^{\circ}$ & $43,235542^{\circ}$ \\
\hline EDR-1 & Edremit-Gölkaşı & $38,351911^{\circ}$ & $43,210157^{\circ}$ \\
\hline EDR-2 & Edremit-Gölkaşı & $38,348092^{\circ}$ & $43,207526^{\circ}$ \\
\hline EDR-3 & Edremit-Dönemeç & $38,336196^{\circ}$ & $43,233035^{\circ}$ \\
\hline EDR-4 & Edremit-Çiçekli & $38,349359^{\circ}$ & $43,190238^{\circ}$ \\
\hline BKC-1 & Van-Merkez-Bakacık & $38,434101^{\circ}$ & $43,344547^{\circ}$ \\
\hline BKC-2 & Van-Merkez-Bakacık & $38,433934^{\circ}$ & $43,344080^{\circ}$ \\
\hline BD-1 & Van-Bardakçı Köyü & $38,568064^{\circ}$ & $43,270740^{\circ}$ \\
\hline CL-1 & Çaldıran & $39,096750^{\circ}$ & $43,913524^{\circ}$ \\
\hline CL-2 & Çaldıran & $39,063667^{\circ}$ & $43,997969^{\circ}$ \\
\hline MR-1 & Muradiye-Merkez & $38,971961^{\circ}$ & $43,723336^{\circ}$ \\
\hline
\end{tabular}


Zeminlerin indeks özelliklerini belirlemek için elek takımı ve hidrometre deney takımı, özgül ağırlık deney seti, Casagrande cihazı kullanılmıştır. Kompaksiyon karakteristiklerini elde etmek amaciyla Standart ve Otomatik Proktor deneylerinde 2,5 kg'lik tokmak, Modifiye Proktor deneyinde ise 4,5 kg'llk tokmak ve hepsinde $10,5 \mathrm{~cm}$ çaplı Proktor kalıbı kullanılmıştır. Konsolidasyon deneyleri sabit halkalı ödometre cihazı kullanılarak gerçekleştirilmiştir.

\subsection{Metot}

Çizelge 1'de konumları verilen killerin [6] bulunduğu arazilerden laboratuvar deneylerini yapmak için örselenmiş numuneler alınmıştır. Numunelerin indeks özelliklerinin belirlenmesi amacıyla özgül ağırlık, tane boyu (elek analizi ve hidrometre) analizi ve Atterberg (kıvam) limitleri deneyleri ASTM [7-11] standartlarına uygun olarak yapılmıştır.

Çalışma kapsamında toplanan zemin numunelerinin her birine Modifiye Proktor, Standart Proktor ve Otomatik Proktor (Standart Proktor tokmağı kullanılarak) kompaksiyon deneyleri yapılarak kompaksiyon eğrileri çizilmiş ve bu eğrilerden optimum su muhtevası ve maksimum kuru birim hacim ağırlık değerleri ASTM D 698 ve D 1557'ye göre [12-13] elde edilmiştir. $\mathrm{Bu}$ su muhtevalarında sıkıştırılan zeminlerden konsolidasyon için örnek alınarak ASTM D 2435'e göre [14] konsolidasyon deneyleri yapılmıştır. Çizelge 2'de kompaksiyon deneylerinde zemine uygulanan kompaksiyon enerjisi değerleri verilmiştir. Otomatik Proktor deneyi, Standart Proktor tokmağı kullanılarak yapıldığı için her iki deneyde uygulanan kompaksiyon enerjileri aynıdır. Bu çalışmada hem aynı sıkıştırma enerjisinde manuel ve makine ile sıkıştırma yapılması durumunda hem de farklı sıkıştırma enerjisinde zeminin mühendislik özelliklerinin nasıl değiştiği araştırılmıştır.

Çizelge 2. Zemine uygulanan kompaksiyon enerjisi miktarları [12-13]

\begin{tabular}{|c|c|}
\hline $\begin{array}{c}\text { Kompaksiyon } \\
\text { Yöntemi }\end{array}$ & $\begin{array}{c}\text { Kompaksiyon Enerjisi (CE) } \\
\left(\mathrm{kN}-\mathrm{m}^{3} \mathrm{~m}^{3}\right)\end{array}$ \\
\hline Standart Proktor & $\sim 600$ \\
\hline Otomatik Proktor & $\sim 600$ \\
\hline Modifiye Proktor & $\sim 2700$ \\
\hline
\end{tabular}

\section{BULGULAR}

Zeminin indeks özelliklerini belirlemek için yapılan deneyler neticesinde Çizelge 3 'te verilen değerler elde edilmiştir. Zeminler, Birleştirilmiş Zemin Sınıflandırma Sistemine (USCS) göre sınıflandırılmıştır. Plastisite kartına bakıldığında numunelerin büyük çoğunluğu düşük plastisiteli kil (CL) olarak sınıflandırılmıştır. CL-2 örneği yüksek plastisiteli kil $(\mathrm{CH}), \mathrm{CL}-1$ örneği ise $\mathrm{ML}$ (düşük plastisiteli silt) veya OL (düşük plastisiteli organik silt-kil) olarak sınıflandırılmıştır (Çizelge 3).

Çizelge 3. Zeminlerin indeks özelliklerini belirlemek için yapılan deney sonuçları

\begin{tabular}{|c|c|c|c|c|c|c|c|c|c|c|}
\hline $\begin{array}{l}\text { Sira } \\
\text { No. }\end{array}$ & $\begin{array}{l}\text { Numune } \\
\text { İşareti }\end{array}$ & $\begin{array}{l}\text { Özgül } \\
\text { Ağırlık }\end{array}$ & & ane $\mathrm{Bo}$ & u (\%) & & & m Lim & & USCS Zemin Sinıfi \\
\hline & & & Kil & Silt & Kum & Çakıl & $\mathrm{w}_{\mathrm{L}}$ & $\mathrm{W}_{\mathrm{P}}$ & $\mathrm{I}_{\mathrm{P}}$ & \\
\hline 1 & GR-1 & 2,63 & 41,70 & 47,60 & 10,70 & 0 & 46,95 & 22,01 & 24,94 & CL \\
\hline 2 & GR-2 & 2,66 & 22,00 & 59,71 & 18,29 & 0 & 29,1 & 20,75 & 8,35 & $\mathrm{CL}$ \\
\hline 3 & GR-3 & 2,63 & 20,10 & 65,46 & 14,44 & 0 & 28,9 & 20,79 & 8,11 & $\mathrm{CL}$ \\
\hline 4 & EDR-1 & 2,66 & 24,00 & 61,10 & 14,90 & 0 & 27,3 & 19,97 & 7,33 & CL \\
\hline 5 & EDR-2 & 2,69 & 36,00 & 60,42 & 3,58 & 0 & 29 & 20,65 & 8,35 & CL \\
\hline 6 & EDR-3 & 2,62 & 33,00 & 53,06 & 13,94 & 0 & 34,3 & 21,49 & 12,81 & CL \\
\hline 7 & EDR-4 & 2,68 & 30,20 & 60,62 & 9,18 & 0 & 30,8 & 20,61 & 10,19 & $\mathrm{CL}$ \\
\hline 8 & BKC-1 & 2,65 & 29,90 & 56,03 & 14,07 & 0 & 32,6 & 19,59 & 13,01 & $\mathrm{CL}$ \\
\hline 9 & BKC-2 & 2,6 & 31,70 & 54,72 & 13,58 & 0 & 37,98 & 23,01 & 14,97 & $\mathrm{CL}$ \\
\hline 10 & BD-1 & 2,65 & 39,80 & 45,07 & 15,13 & 0 & 42,4 & 21,6 & 20,8 & $\mathrm{CL}$ \\
\hline 11 & CL-1 & 2,5 & 27,00 & 54,06 & 18,94 & 0 & 37,25 & 28,98 & 8,27 & ML veya OL \\
\hline 12 & CL-2 & 2,68 & 50,00 & 42,02 & 7,98 & 0 & 61,4 & 28,41 & 32,99 & $\mathrm{CH}$ \\
\hline 13 & MR-1 & 2,66 & 20,20 & 64,95 & 14,85 & 0 & 30,7 & 22,47 & 8,23 & $\mathrm{CL}$ \\
\hline
\end{tabular}


Çalışma kapsamında araziden toplanan örselenmiş zemin numuneleri üzerinde Standart, Otomatik (Standart Proktor tokmağ 1 kullanılarak) ve Modifiye Proktor enerji seviyelerinde su içeriği arttırılarak her bir deneyde beş farklı su içeriğinde kompaksiyon deneyleri yapılmıştır. Elde edilen veriler kullanılarak kompaksiyon eğrileri çizilmiştir (Şekil 3-6). Bu eğrilerden zeminlere ait maksimum kuru birim hacim ağırlık ve optimum su muhtevası değerleri belirlenmiştir.

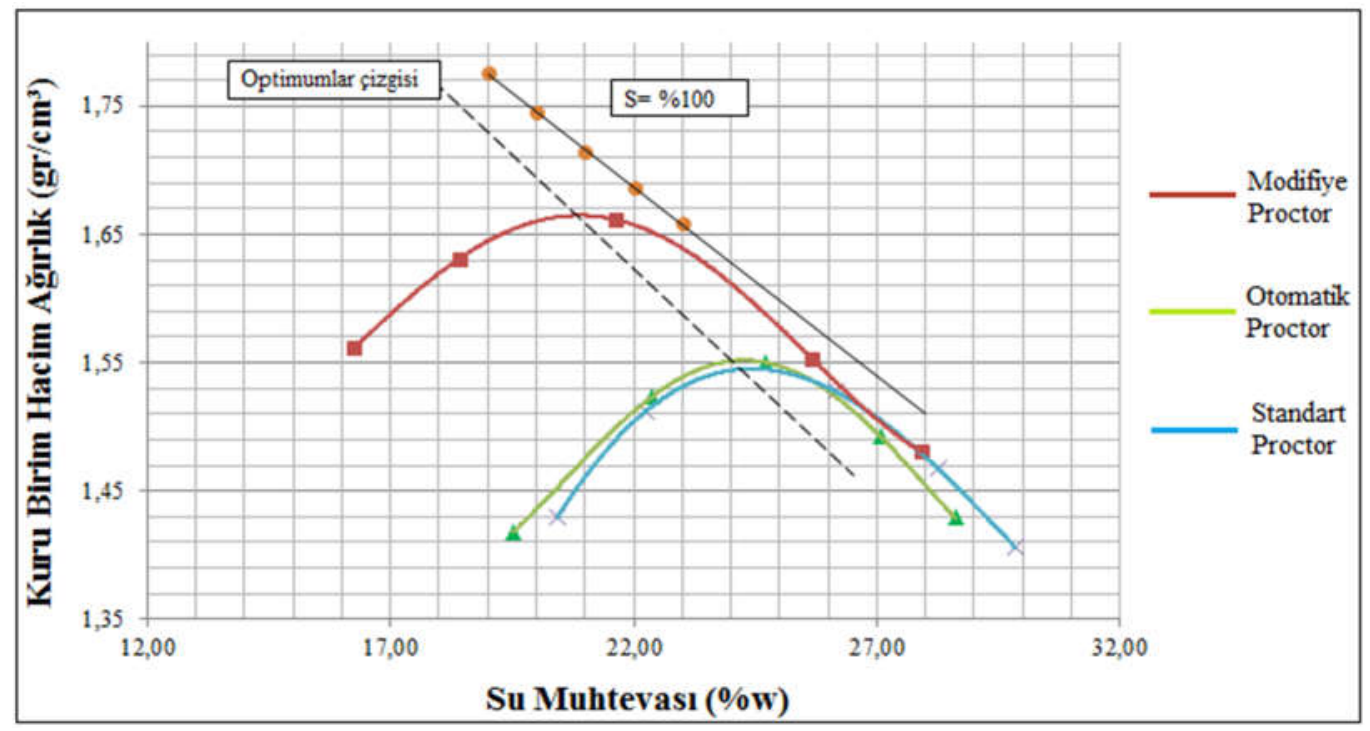

Şekil 3. CL-2 Proktor deneylerinin kompaksiyon eğrileri

Şekil 3, Şekil 4 ve Şekil 5'teki kompaksiyon grafikleri optimumdan kuru, optimum ve optimumdan ıslak olmak üzere üç ayrı kısımda yorumlanmıştır. Standart ve Otomatik Proktor deneylerinde uygulanan sıkıştırma enerjisi aynı olduğu için bunlar birbiri içerisinde değerlendirilmiştir. Modifiye Proktor deneyinde Standart ve Otomatik Proktor deneylerine göre daha yüksek sıkıştırma enerjisi uygulanmıştır.

Kompaksiyon eğrilerinin optimumdan kuru bölgelerine bakıldığında, eğrilerin birbirine yaklaşık olarak paralel durumda olduğu görülmektedir. $\mathrm{Bu}$ durum sıkıştırma enerjisindeki farkın önemli ölçüde olduğunu göstermektedir.

Eğrilerin optimum bölgelerine bakıldığında, enerjideki artışa bağlı olarak eğri pik noktalarının sola doğru kaydığı ve yükseldiği görülmektedir. $\mathrm{Bu}$ değişim, kompaksiyon enerjisindeki artışa bağlı olarak optimum su muhtevasının azaldığını, kuru birim hacim ağırlığın ise arttığını göstermektedir.
Eğrilerin optimumdan 1slak bölgelerine bakıldığında ise eğrilerin birbirini kestiği gözlenmektedir. Bu durumun sebebi, optimumdan sslak bölgede, zemin içerisinde fazla miktarda su bulunması ve suyun sıkıştırılamaz olmasından kaynaklanmaktadır.

Kompaksiyon eğrilerinin maksimum noktalarından geçen çizgi optimumlar çizgisidir. Bu çizgi \%100 doygunluk çizgisi ile yaklaşık olarak paraleldir. $\mathrm{Bu}$ paralellik, iki çizgide de su muhtevası düşerken kuru birim hacim ağırlığın artmasından kaynaklanmaktadır.

Kompaksiyon eğrileri genel olarak incelendiğinde, bütün eğrilerin \%100 doygunluk çizgisinin solunda kaldığ 1 görülmektedir. Bu durum, kompaksiyon enerjisindeki artışa rağmen zeminin içerisinde bir miktar hava kaldığını göstermektedir. Kompaksiyon eğrisinin pik noktasındaki doygunluk derecesi ne kadar yüksek olursa o kadar iyi bir sıkıştırma elde edilir. 
Standart ve Otomatik Proktor eğrileri genel olarak incelendiğinde ise aynı sıkıştırma enerjisi uygulanmasına rağmen Otomatik Proktor deneyinde az da olsa yüksek kuru birim hacim ağırlık ve daha düşük su muhtevası değerleri elde edilmiștir. $\mathrm{Bu}$ durum, Otomatik Proktor aletinin düzenli bir vuruş sisteminin olması ve darbelerin zemin yüzeyine eşit olarak dağılmasından ve her vuruş için istenilen vuruş yüksekliğinin tam olarak sağlanmasından kaynaklanmaktadır.

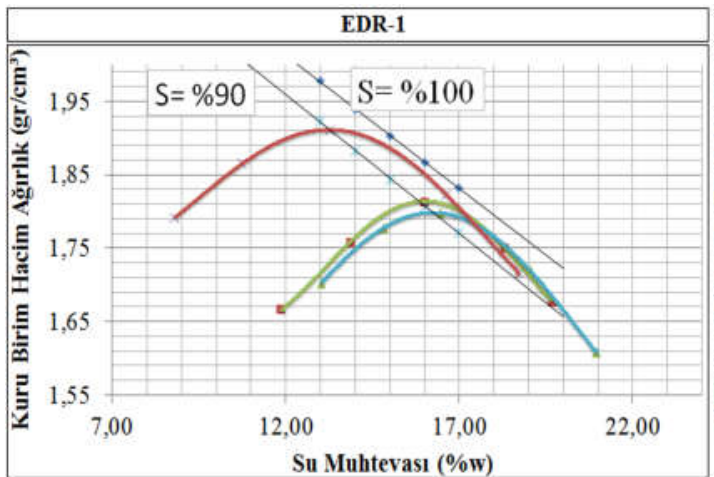

(a)

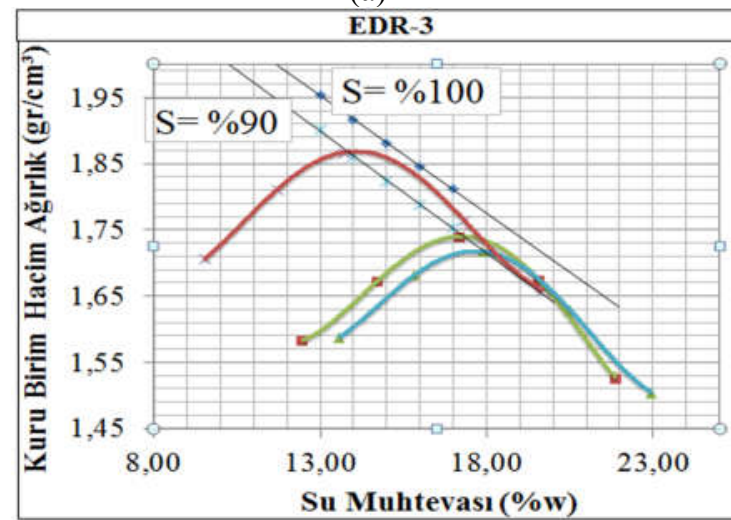

(c)

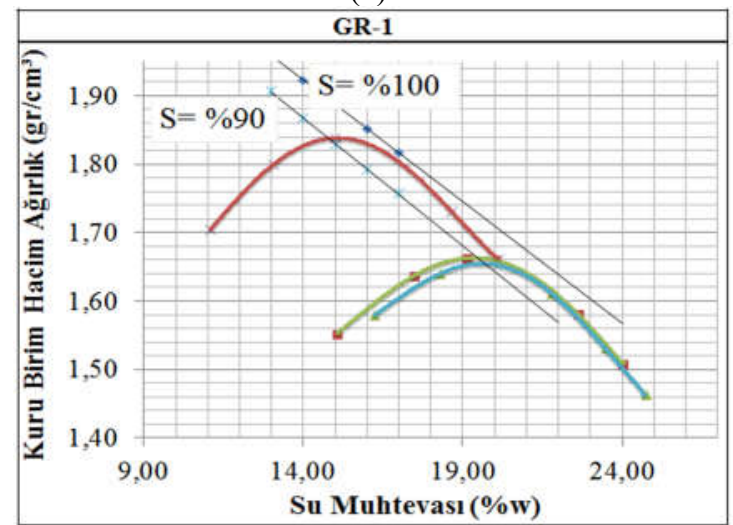

(e)

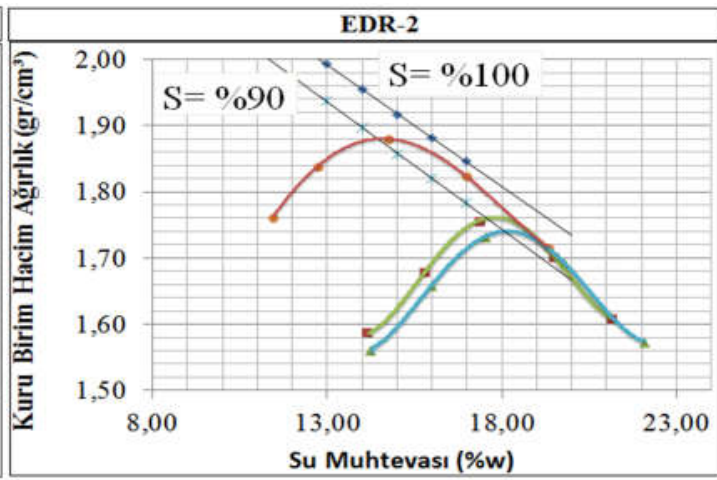

(b)

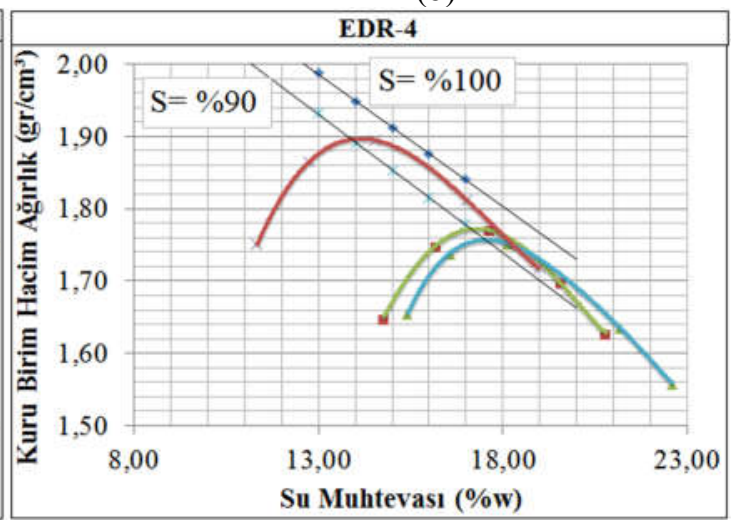

(d)

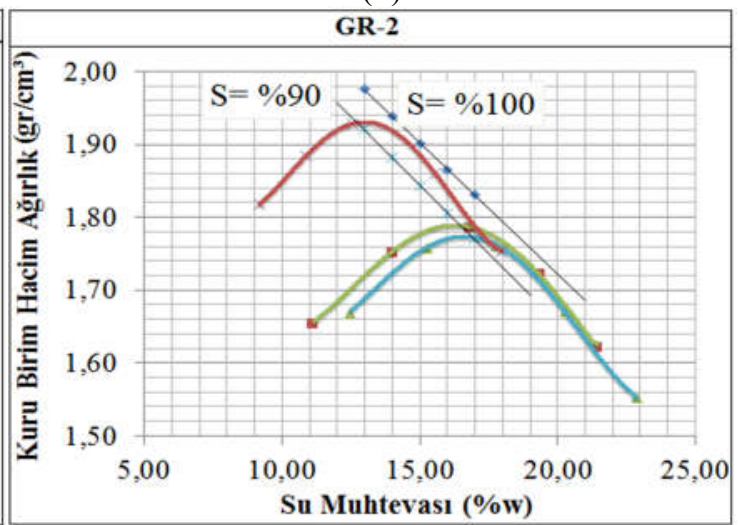

(f)

Şekil 4. Çalışma kapsamındaki zeminlerin kompaksiyon grafikleri, a) EDR-1, b) EDR-2, c) EDR-3, d) EDR-4, e) GR-1, f) GR-2 


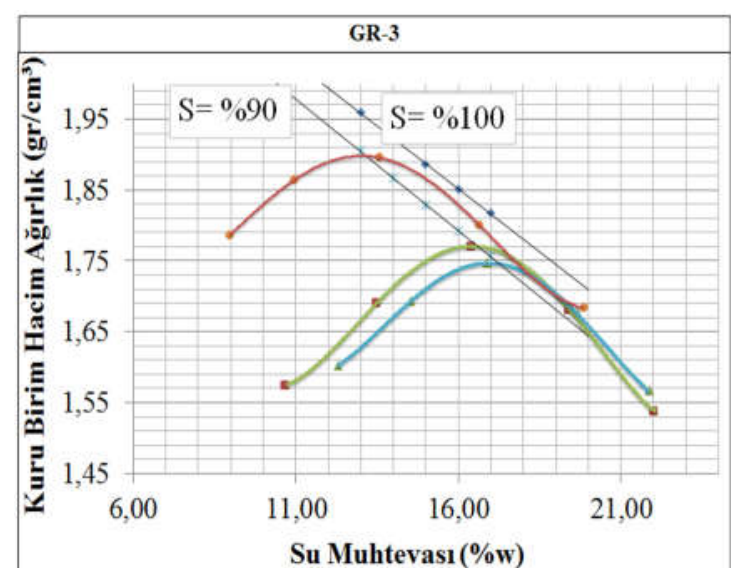

(a)

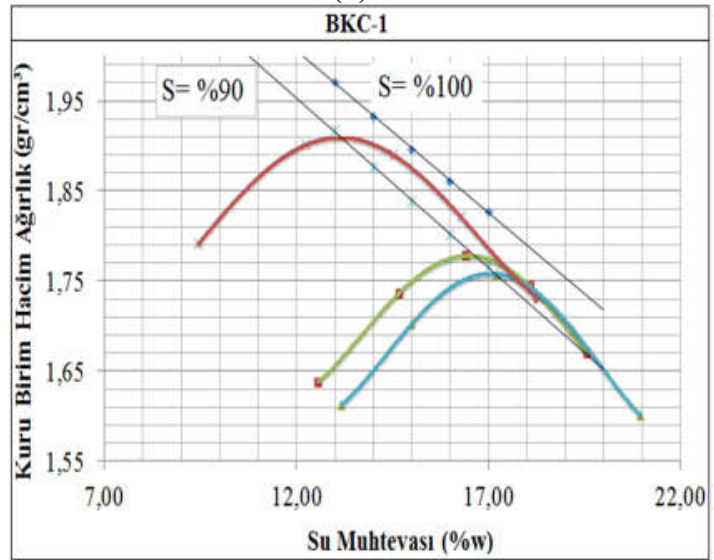

(c)

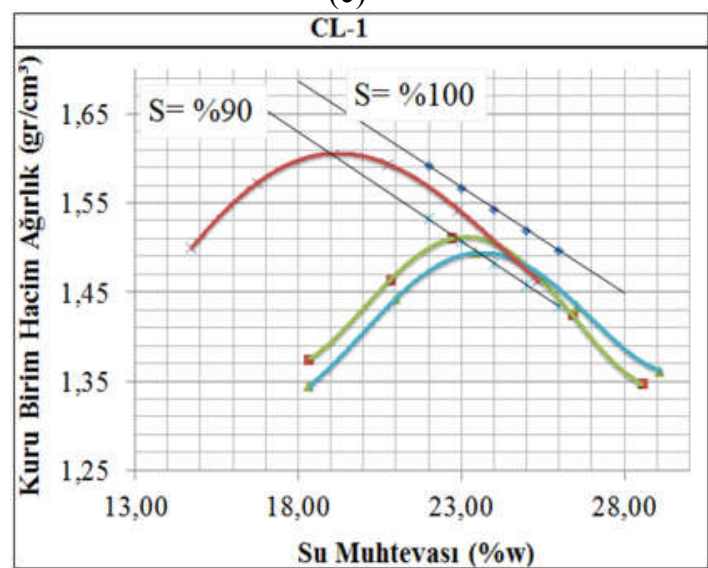

(e)

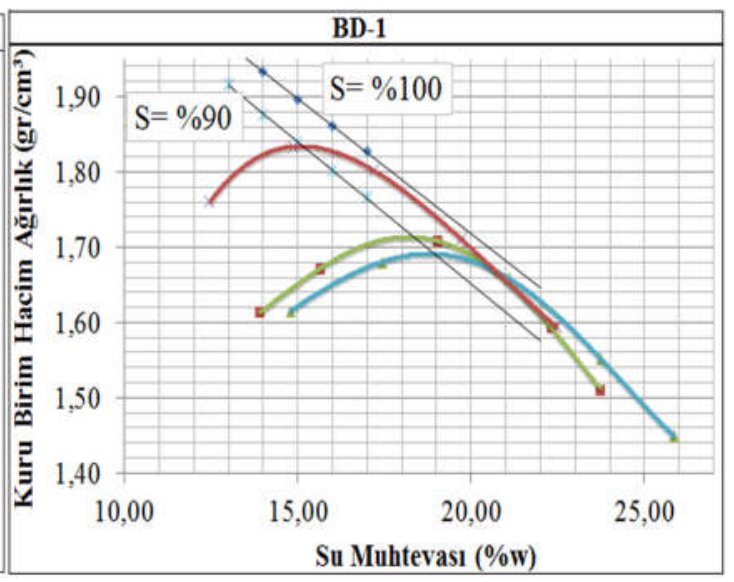

(b)

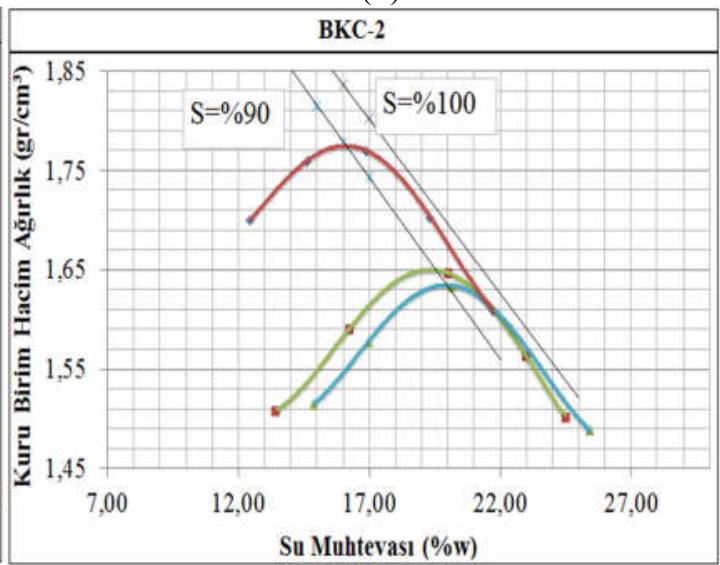

(d)

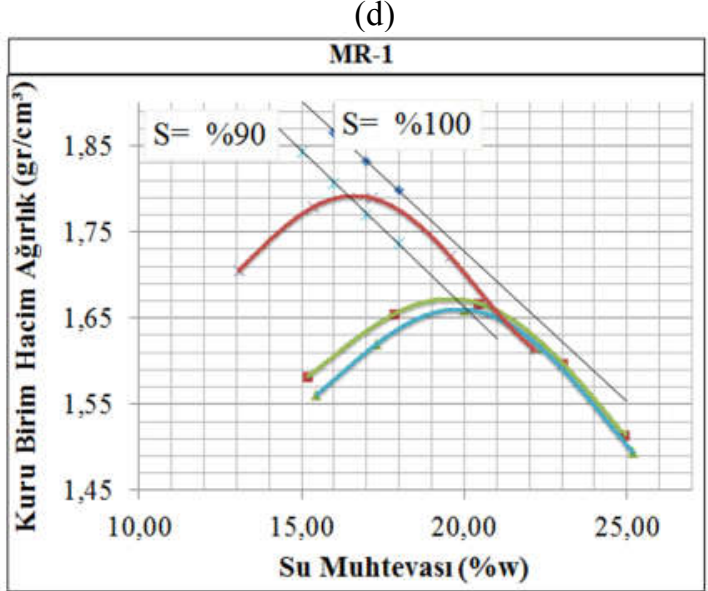

(f)

Şekil 5. Çalışma kapsamındaki zeminlerin kompaksiyon grafikleri, a) GR-3, b) BD-1, c) BKC-1, d)BKC2, e) CL-1, f) MR-1 
Dolgular sıkıştırılmış yapılar olmasına rağmen zaman geçtikçe hem üzerine inşa edilen yapıların hem de dolgunun kendi ağırlığından kaynaklı oturmalar oluşabilir. Dolgu üzerine inşa edilen yapıların zarar görmemesi için bu oturmaların belirli sınırlar içinde olması istenir. Bu yüzden zeminde oluşacak oturma miktarı hesaplanmalıdır. $\mathrm{Bu}$ oturma miktarı konsolidasyon deneyi ile bulunur. Ön konsolidasyon basinc1 veya efektif gerilme $\left(\sigma_{\mathrm{p}}\right)$ zeminde oluşacak olan oturmanın bir ölçüsüdür.
Standart, modifiye ve otomatik Proctor kompaksiyon deneyleri sonucu belirlenen maksimum sıkışmanın elde edildiği su muhtevası değerlerinde yeniden sıkıştırılan zemin örnekleri üzerinde konsolidasyon deneyleri yapılmıştır. Konsolidasyon deneyi sonucunda, farklı kompaksiyon yöntemleri ile sıkıştırılan zeminlerin Casagrande [15] yöntemi ile ön konsolidasyon basınçları ve gerilme altındaki davranışları belirlenmiştir (Şekil 6-8).

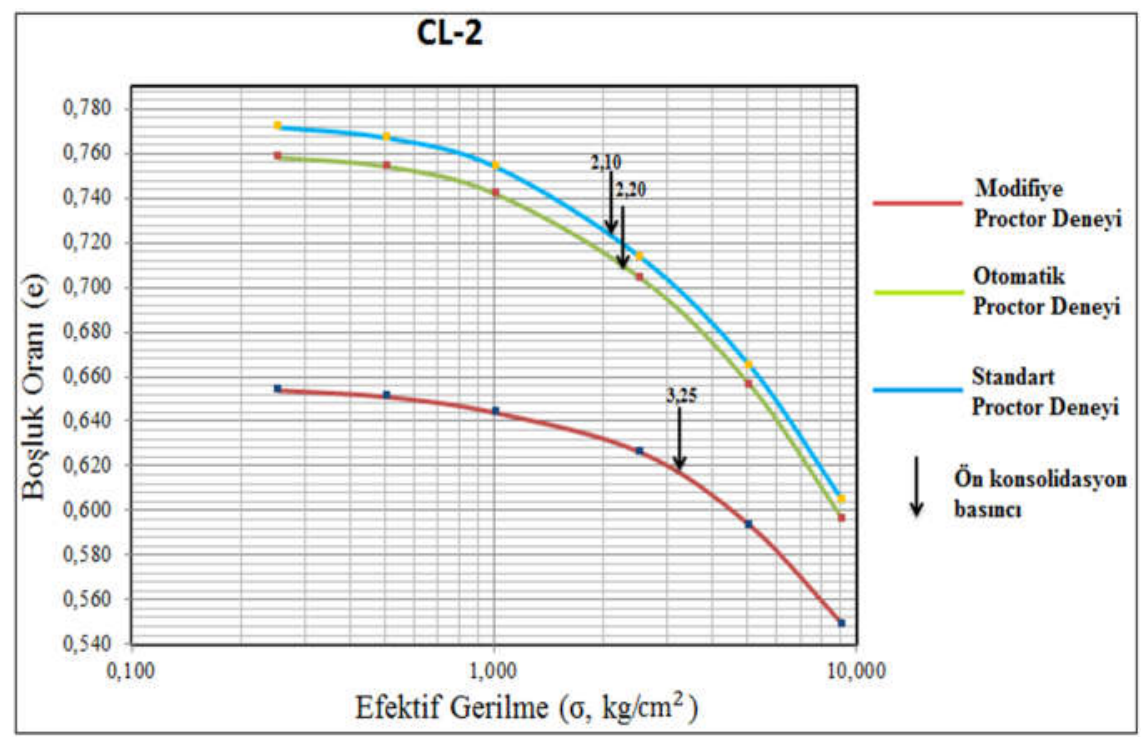

Şekil 6. CL-2 kompaksiyon deneylerine karşılık gelen konsolidasyon eğrileri

Şekil 6-8'deki konsolidasyon grafikleri incelendiğinde konsolidasyon eğrilerinin hepsinde efektif gerilmedeki artışa bağlı olarak boşluk oranının azaldığı görülmektedir. $\mathrm{Bu}$ durumun nedeni zeminin maruz kaldığ 1 gerilme değerindeki artışa bağlı olarak zeminin boşluklarındaki su ve havanın dışarı atılması ve zemin tanelerinin daha sıkı bir yapıya sahip olmasıdır. Ayrıca boşluk oranı değerleri, ön konsolidasyon basıncının altındaki gerilmelerde çok fazla değişmezken, ön konsolidasyon basıncından yüksek gerilmelerde çok fazla azalmaktadır. $\mathrm{Bu}$ durum göz önüne alınacak olursa zemine uygulanacak gerilmelerin; ön konsolidasyon basıncından yüksek olması halinde zeminde oluşacak deformasyonların fazla, ön konsolidasyon basıncından düşük olması halinde ise bu deformasyonların daha az olacağı söylenebilir.

Konsolidasyon grafikleri genel olarak incelendiğinde kompaksiyon enerjisindeki artışa bağlı olarak boşluk oranlarının azaldığı, ön konsolidasyon basınçlarının ise arttığı görülmektedir. Kompaksiyon enerjisindeki artış, tanelerin birbirlerine daha fazla yaklaşmasına ve kenetlenmesine neden olduğu için zemindeki boşluk oranı azalır ve böylece ön konsolidasyon basıncı artar. Boşluk oranı kompaksiyon enerjisindeki artışa bağlı olarak azalmasına rağmen kompaksiyon eğrilerinin \%100 doygunluk çizgisi ile kesilmemesi zemin içerisinde her zaman bir miktar boşluk kaldığını göstermektedir. 


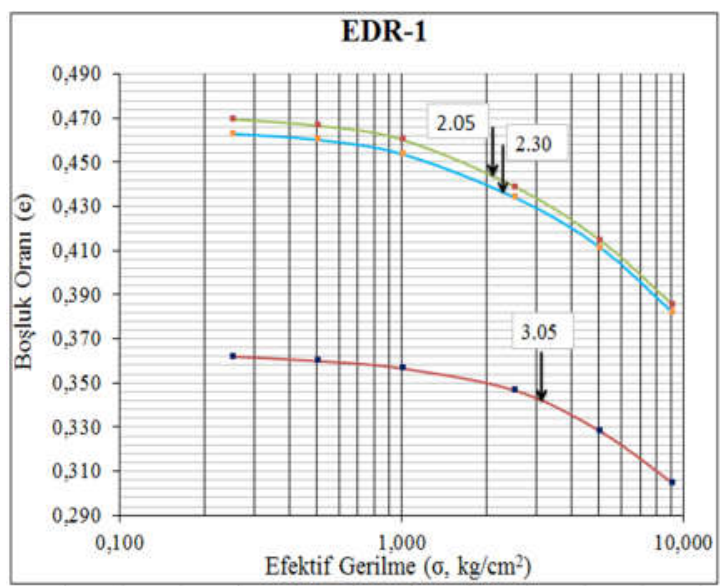

(a)

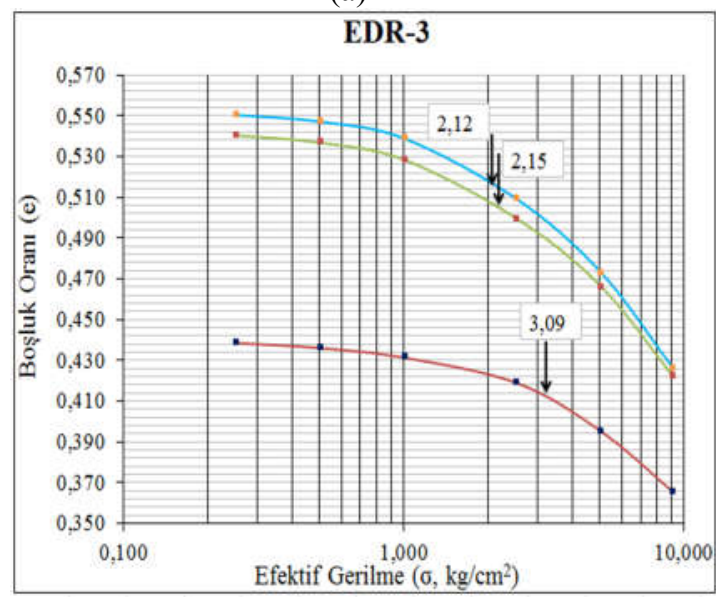

(c)

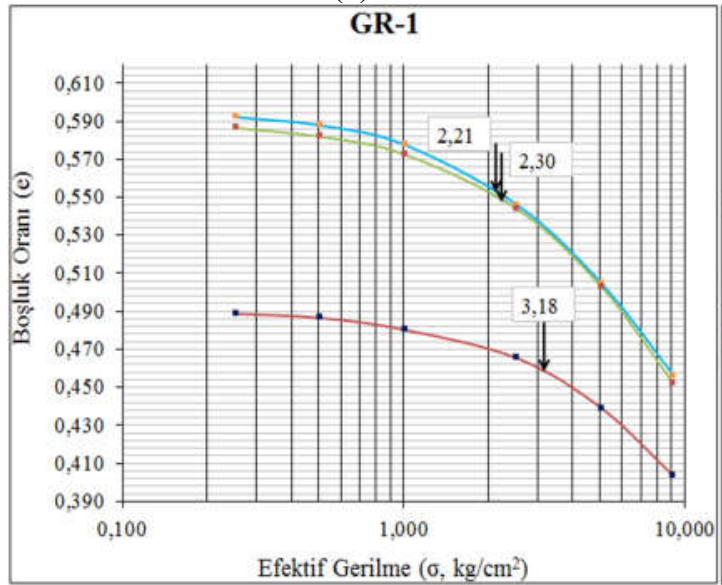

(e)

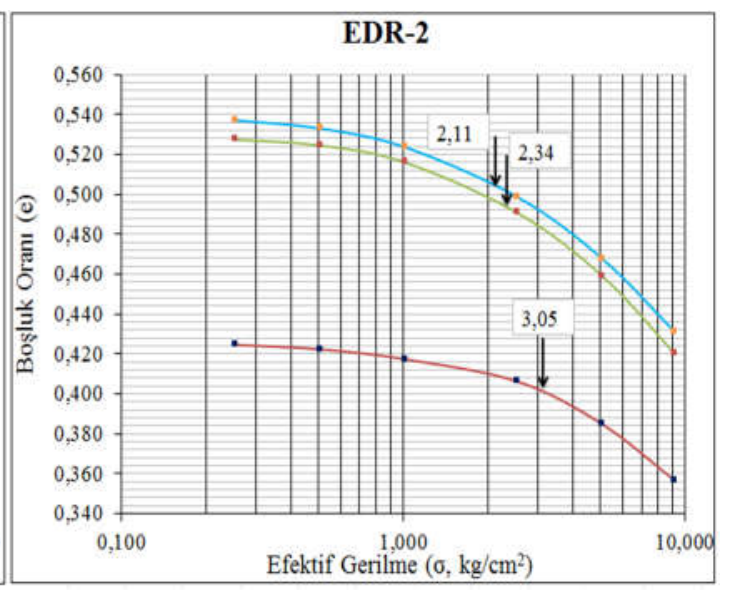

(b)

EDR-4

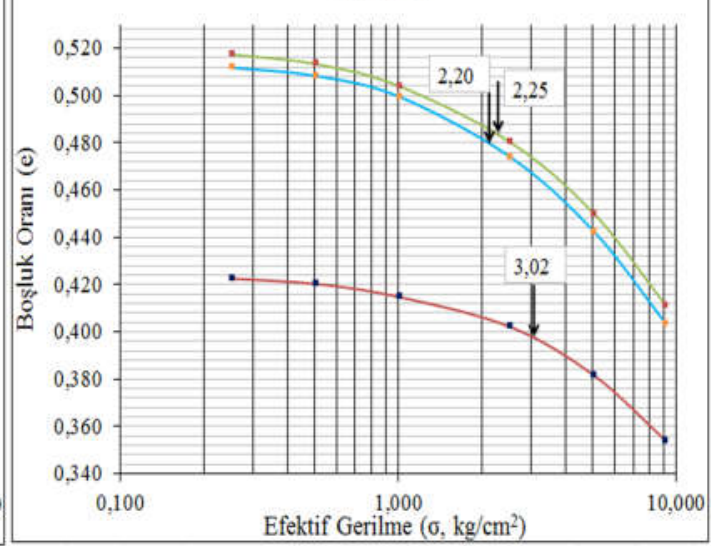

(d)

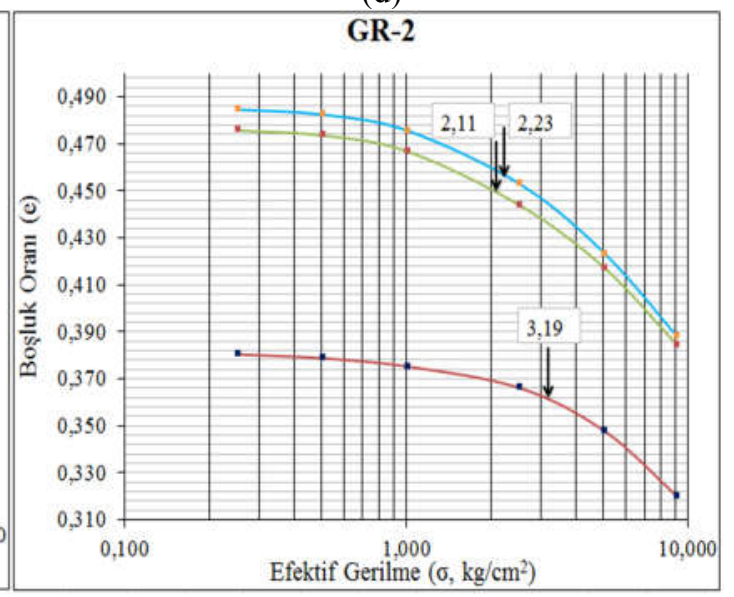

(f)

Şekil 7. Çalışma kapsamındaki zeminlerin konsolidasyon grafikleri, a) EDR-1, b) EDR-2, c) EDR-3, d) EDR-4, e) GR-1, f) GR-2 


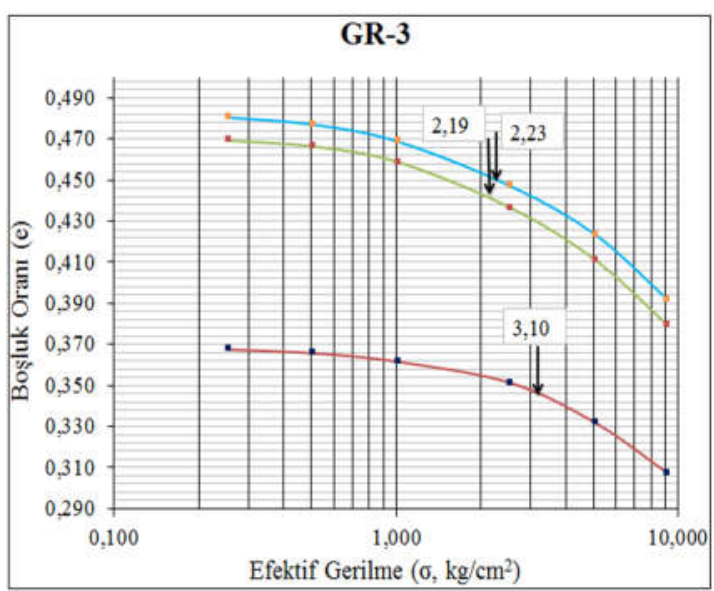

(a)

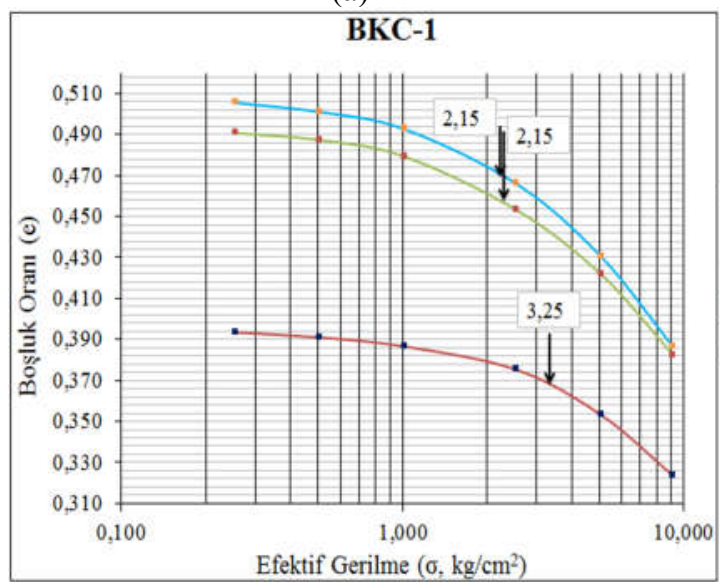

(c)

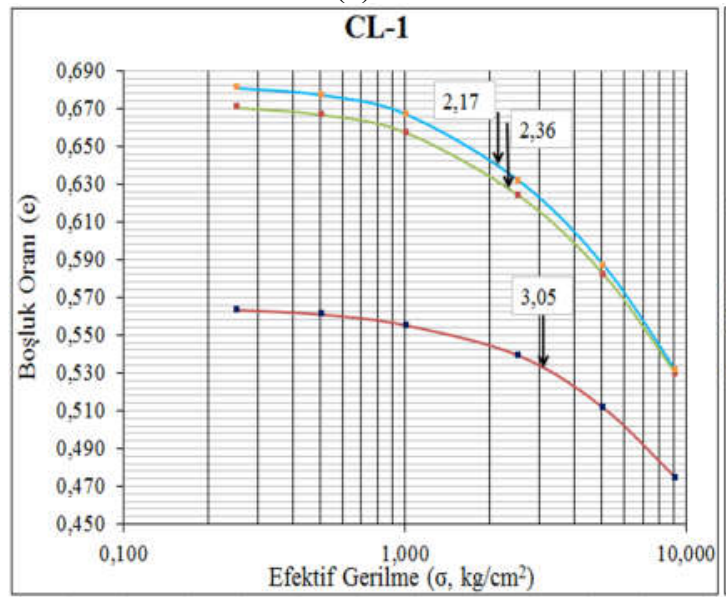

(e)

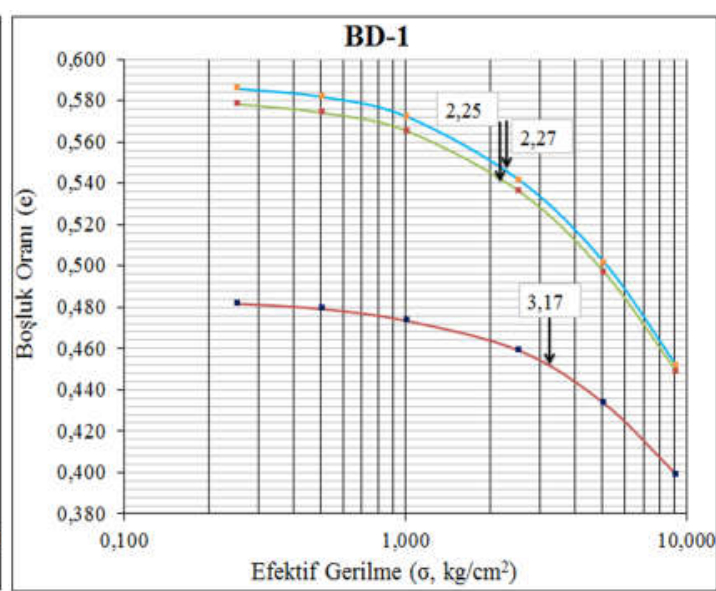

(b)

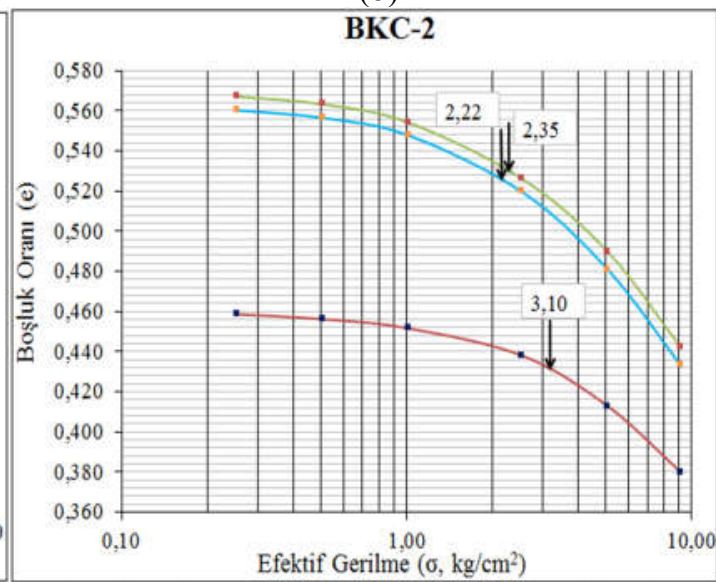

(d)

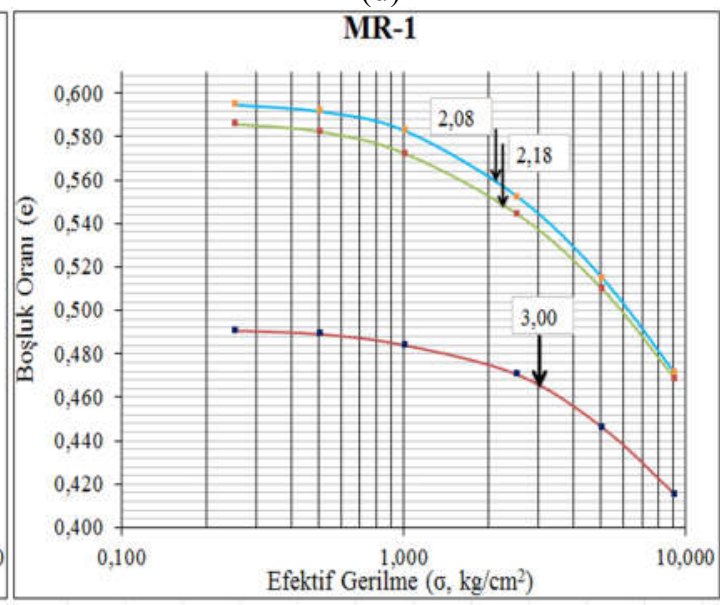

(f)

Şekil 8. Çalışma kapsamındaki zeminlerin konsolidasyon grafikleri, a) GR-3, b) BD-1, c) BKC-1, d) BKC-2, e) CL-1, f) MR-1 
3.1. Plastik Limit $\left(w_{p}\right)$ ile Maksimum Kuru Birim Hacim Ağırlık $\left(\gamma_{k-m a x}\right)$ ve Optimum Su Muhtevası $\left(\omega_{\text {opt }}\right)$ Arasındaki İlişkiler

Deneysel çalışmalar sonrasında elde edilen veriler arasındaki bazı ilişkiler incelenmiştir. Şekil 9'da görüldüğü gibi maksimum kuru birim hacim ağırlık ile plastik limit arasında yüksek korelasyon ilişkisi elde edilmiştir. Her üç tip Proktor deneyinden elde edilen maksimum kuru birim hacim değerlerinin plastik limit ile yüksek korelasyon katsayısına sahip olduğu ve her iki değer arasında azalan bir doğrusal ilişkinin olduğu belirlenmiştir.
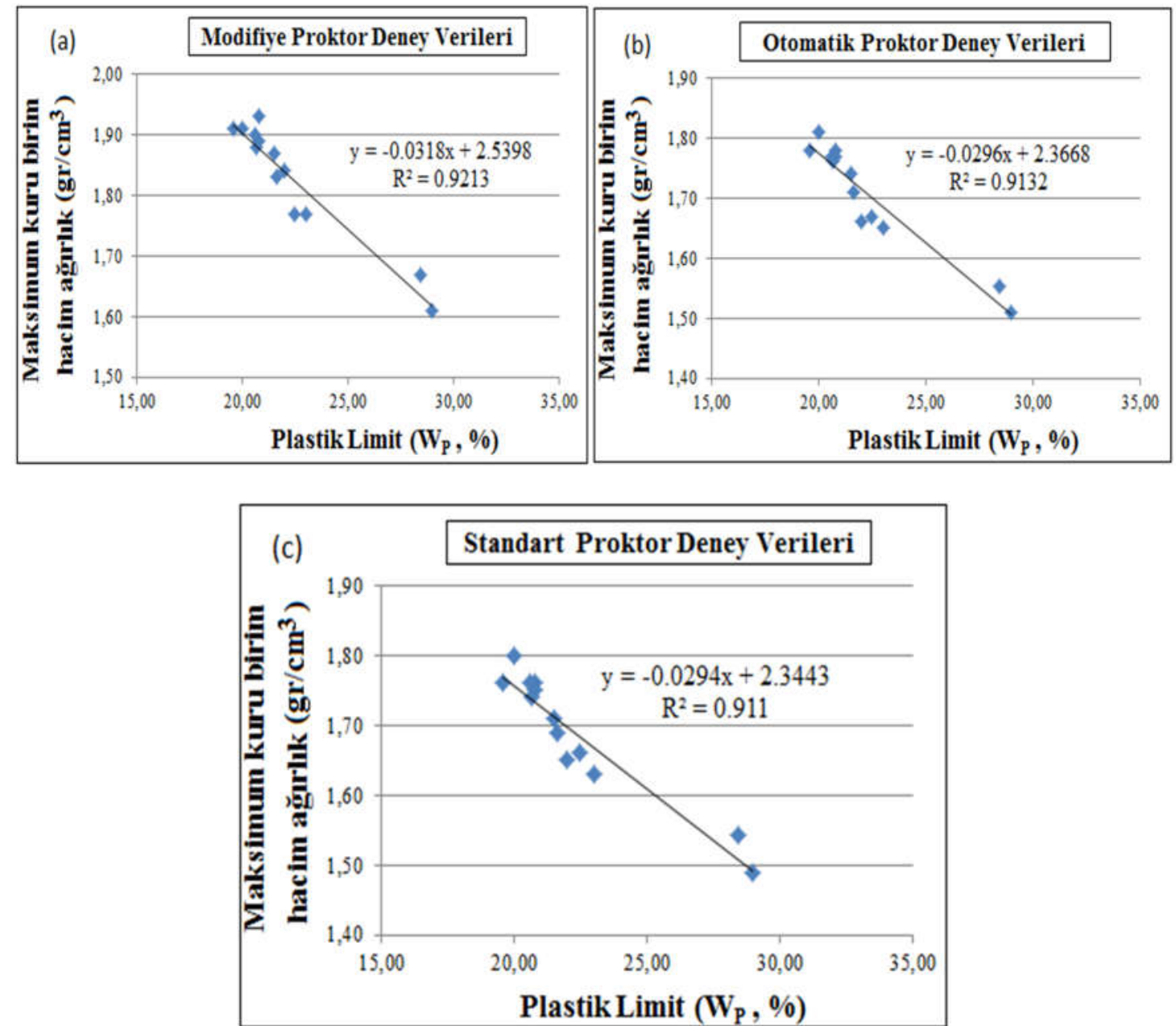

Şekil 9. Plastik limit $\left(\mathrm{w}_{\mathrm{p}}\right)-$ maksimum kuru birim hacim ağırlık $\left(\gamma_{\mathrm{k}-\mathrm{max}}\right)$ ilişkisi a) Modifiye Proktor, b) Otomatik Proktor ve c) Standart Proktor deney veriler

Şekil 10’da görüldüğü gibi plastik limit ile optimum su muhtevası arasında da yüksek korelasyona sahip bir ilişkiye rastlanmıştır. Bu ilişkide maksimum kuru birim hacim ağırlık ile olan ilişkinin tersine her iki değer arasında artan doğrusal bir ilişki elde edilmiştir. 

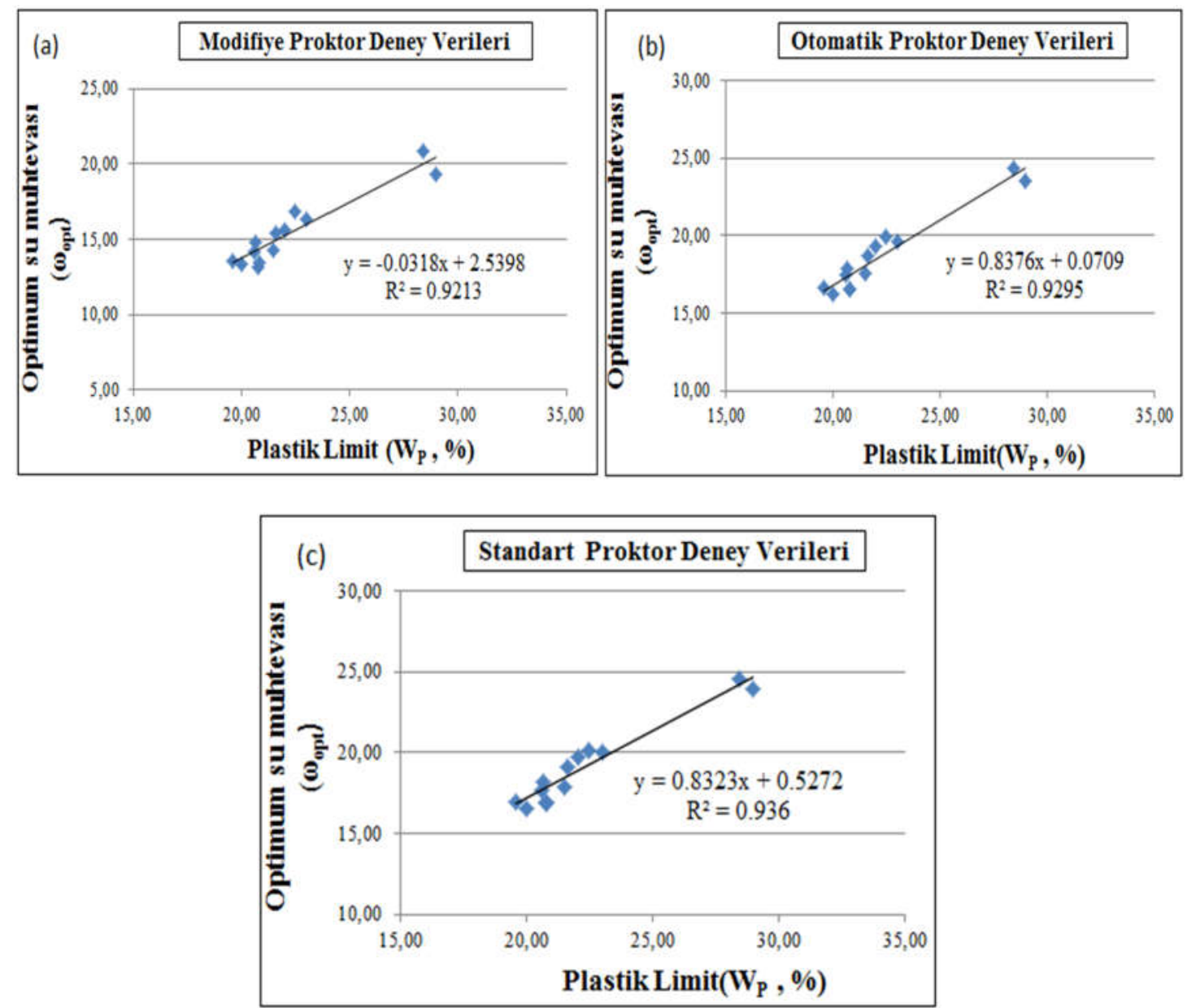

Şekil 10. Plastik limit $\left(\mathrm{w}_{\mathrm{p}}\right)$ - Optimum su muhtevası $\left(\omega_{\mathrm{opt}}\right)$ ilişkisi a) Modifiye Proktor, b) Otomatik Proktor ve c) Standart Proktor deney verileri

Elde edilen bu ilişkiler, kil zeminlerde laboratuvarda kolay belirlenebilen Plastik Limit değeri ile Proktor değerlerinin tahmininde kullanılarak, malzemenin sıkışabilirlik özelliklerini hızlı değerlendirmede yol gösterici olabilir. Her ne kadar bu çalışmada kullanılan killer için bu parametreler arasında yüksek korelasyon katsayıları elde edilmiş olsa da, çalışmada kullanılan numune sayısı 13 ile sınırlı kalmıştır. Korelasyon grafiklerinden elde edilen denklemlerin daha kullanılabilir olması için numune sayısının arttırılarak eşitliğin güvenilirliğinin arttırılması önerilmektedir.

\subsection{Van Gölü Çevresindeki Killerin Sıkışabilirlik Değerlendirmesi \\ Özelliklerinin}

Zeminlerin yol dolgularında veya kil çekirdek dolgu barajlarda kullanılabilmesi için belirli şartları sağlamaları gerekmektedir. $\mathrm{Bu}$ şartlar Karayolları Teknik Şartnamesi [16] ve DSİ Teknik Şartnamesi'nde [17] yer almaktadır.

Van Gölü etrafındaki 13 farklı noktadan alınan kil zeminlere ait Proktor değerleri mühendislik yapılarında kullanılabilirlik açısından da değerlendirilmiştir. Çalışmada kullanılan kil numunelerinden elde edilen tüm sonuçlar her iki 
şartnameye göre değerlendirildiğinde, Proktor değerleri açısından Van Gölü kuzeyindeki organik içerikli CL-1 numunesi ile Plastisite İndisi yüksek olan CL-2 numunesinin KGM Teknik Şartnamesine uygun olmadığı belirlenmiştir
(Çizelge 4). DSİ Şartnamesi açısından ise sadece Bakacık bölgesindeki BKC-2 ve Bardakçı bölgesindeki BD-1 numunelerinin sıkışma özelliklerinin uygun olduğu tespit edilmiştir (Çizelge 4).

Çizelge 4. Zeminlerin şartname sınırları uygunluk kontrolü

\begin{tabular}{|c|c|c|c|c|c|c|c|}
\hline Numune No & $\begin{array}{c}\text { Numune } \\
\text { Kodu }\end{array}$ & $\begin{array}{c}\text { Özgül } \\
\text { Ağıllk } \\
\left(\mathrm{G}_{\mathrm{s}}\right)\end{array}$ & $\begin{array}{c}\text { Likit } \\
\text { Limit } \\
(\mathrm{LL})\end{array}$ & $\begin{array}{c}\text { Standart Proktor Max. } \\
\text { kuru birim hacim ağırlik } \\
\left(\mathrm{gr} / \mathrm{cm}^{3}\right)\end{array}$ & $\begin{array}{c}\text { Plastisite } \\
\text { Indisi (\%) }\end{array}$ & $\begin{array}{c}\text { KGM } \\
\text { Teknik } \\
\text { Şartname }\end{array}$ & $\begin{array}{c}\text { DSI } \\
\text { Teknik } \\
\text { Şartname }\end{array}$ \\
\hline 1 & GR-1 & 2,63 & 46,95 & 1,65 & 24,94 & $\checkmark$ & $\mathrm{X}$ \\
\hline 2 & GR-2 & 2,66 & 29,1 & 1,76 & 8,35 & $\checkmark$ & $\mathrm{X}$ \\
\hline 3 & GR-3 & 2,63 & 28,9 & 1,75 & 8,11 & $\checkmark$ & $\mathrm{X}$ \\
\hline 4 & EDR-1 & 2,66 & 27,3 & 1,80 & 7,33 & $\checkmark$ & $\mathrm{X}$ \\
\hline 5 & EDR-2 & 2,69 & 29 & 1,74 & 8,35 & $\checkmark$ & $\mathrm{X}$ \\
\hline 6 & EDR-3 & 2,62 & 34,3 & 1,71 & 12,81 & $\checkmark$ & $\mathrm{X}$ \\
\hline 7 & EDR-4 & 2,68 & 30,8 & 1,76 & 10,19 & $\checkmark$ & $\mathrm{X}$ \\
\hline 8 & BKC-1 & 2,65 & 32,6 & 1,76 & 13,01 & $\checkmark$ & $\mathrm{X}$ \\
\hline 9 & BKC-2 & 2,6 & 37,98 & 1,63 & 14,97 & $\checkmark$ & $\checkmark$ \\
\hline 10 & BD-1 & 2,65 & 42,4 & 1,69 & 20,8 & $\checkmark$ & $\checkmark$ \\
\hline 11 & CL-1 & 2,5 & 37,25 & 1,49 & 8,27 & $\mathrm{X}$ & $\mathrm{X}$ \\
\hline 12 & CL-2 & 2,68 & 61,4 & 1,54 & 32,99 & $\mathrm{X}$ & $\mathrm{X}$ \\
\hline 13 & MR-1 & 2,66 & 30,7 & 1,66 & 8,23 & $\checkmark$ & $\mathrm{X}$ \\
\hline Uygulanan & KGM & - & $\leq 60$ & $\geq 1,45$ & $\leq 35$ & & \\
\hline & DSI & $2,5-2,8$ & $40-50$ & $1,43-1,87$ & $14-20$ & & \\
\hline
\end{tabular}

\section{SONUÇLAR}

$\mathrm{Bu}$ çalışmanın sonucunda; kompaksiyon eğrilerinin optimum bölgelerine bakıldığında, enerjideki artışa bağlı olarak eğri pik noktalarının sola doğru kaydığı ve yükseldiği görülmektedir. $\mathrm{Bu}$ değişim, kompaksiyon enerjisindeki artışa bağlı olarak optimum su muhtevasının azaldığını, kuru birim hacim ağırlığın ise arttığını göstermektedir.

İncelenen numunelerin optimum su muhtevas1, Modifiye Proktor deneylerinde 13,2 ile 20,9 arasinda, Standart Proktor deneylerinde 16,5 ile 24,5 arasında ve Otomatik Proktor deneylerinde 16,2 ile 24,3 arasında belirlenmiştir. En yüksek su muhtevası değerleri Van Gölünün en kuzeyindeki CL-1 ve CL-2 numunelerinde, en düşük su muhtevası değerleri ise en güneyindeki EDR-1 ve GR-2 numunelerinde elde edilmiştir.

Kompaksiyon eğrilerinin optimumdan kuru bölgesine bakıldığında, eğrilerin birbirine yaklaşık paralel durumda olduğu görülürken optimumdan sslak bölgede ise birbirini kesmiştir. $\mathrm{Bu}$ durum optimumdan kuru bölgede sıkıştırma enerjisindeki farkın önemli ölçüde olduğunu, optimumdan ıslak bölgede ise bir noktadan sonra sıkıștırma enerjisindeki artışın zemin sıkışmasına herhangi bir etkisinin olmadığını ortaya koymaktadır.

Ayrıca bütün kompaksiyon eğrilerinin \%100 doygunluk çizgisinin solunda kaldığı yani kompaksiyon enerjisindeki artışa rağmen zeminin içerisinde bir miktar hava kaldığı tespit edilmiştir.

Standart ve Otomatik Proktor kompaksiyon eğrilerinden, aynı sıkıştırma enerjisi $\left(600 \mathrm{kN}-\mathrm{m} / \mathrm{m}^{3}\right)$ uygulanmasına rağmen Otomatik Proktor deneyinde az da olsa yüksek kuru birim hacim ağırlık ve daha düşük su muhtevası değerleri elde edilmiştir.

Konsolidasyon deneylerinde ise Standart ve Otomatik Proktor yöntemi ile sıkıştırılan numunelere aynı sıkıştırma enerjisi uygulandığı 
için birbirine yakın boşluk oranı ve ön konsolidasyon basıncı değerleri elde edilmiştir.

Tüm zeminlerin konsolidasyon grafikleri genel olarak incelendiğinde kompaksiyon enerjisindeki artışa bağlı olarak boşluk oranlarının azaldığı, ön konsolidasyon basınçlarının ise arttı̆̆ görülmektedir

Çalışma sonucunda, seçilen zemin numunelerinin plastik limit değeri ile maksimum kuru birim hacim ağırlığı arasında doğrusal azalan, optimum su muhtevası ile de doğrusal artan yüksek korelasyon katsayısına sahip bir ilişki elde edilmiştir. Ancak denklemlerin kullanılabilir olması için numune sayısının arttırılarak denklemlerin güvenilirliğinin arttırılması önerilmektedir.

Van Gölü etrafındaki killerin sıkışabilirlik özellikleri değerlendirildiğinde, CL-1 (Proktor değeri sınırda olduğu için) ve CL-2 (LL>60 olduğu için) haricindeki tüm killerin Karayolları Teknik Şartnamesine (2013) göre yol dolgularında kullanılabileceği belirlenmiştir. DSİ (1993) şartnamesine göre Van Gölü etrafindaki killer değerlendirildiğinde ise, sadece BKC-2 ve BD-1 numunelerinin kil çekirdek dolgu tipi barajların kil çekirdek kısmında kullanılabilir nitelikte olduğu tespit edilmiştir.

\section{TEŞEKKÜR}

$\mathrm{Bu}$ çalışmada bilgi ve birikimleri ile her türlü desteği veren kiymetli hocam Dr. Öğr. Üyesi Mehmet TÜRKMENOĞLU'na, arazi ve laboratuvar çalışmalarında çok büyük katkısı olan Jeoloji Mühendisi Engin TURGUT'a teşekkür ederim. $\mathrm{Bu}$ çalışma, VAN Yüzüncü Yıl Üniversitesi Bilimsel Araştırma Projeleri Koordinasyon Birimi tarafindan FYL-2018-6852 No'lu proje olarak desteklenmiştir.

\section{KAYNAKLAR}

1. Aytekin, M., 2004. Compaction-Related Tests, Teknik Yayınevi, 624, Ankara.
2. Lambe, T.W., 1958a. The Structure of Compacted Clay, Journal of the Soil Mechanics and Foundations Division, 84 (1654), 1-34.

3. Lambe, T.W., 1962. Foundation Engineering, Chap.4. Soil Stabilization, Mc. Graw-Hill, 88, New York.

4. Lambe, T.W., 1958b. The Structure of Compacted Clay, Journal of the Soil Mechanics and Foundations Division, 84 (1655), 1-34.

5. Cetin, H., Fener, M., Soylemez, M., Gunaydin, O., 2007. Soil Structure Changes During Compaction of a Cohesive Soil, Engineering Geology, 92, 38-48.

6. Ateş, Y., 2010. Van Gölü Havzası Killerinin Mineralojik, Fiziksel, Kimyasal Özellikleri ve Kullanım Alanlarının Belirlenmesi (Doktora Tezi). YYÜ, Fen Bilimleri Enstitüsü, Van.

7. ASTM D854-14, 2014. Standard Test Methods for Specific Gravity of Soil Solids by Water Pycnometer, ASTM International, West Conshohocken, PA, www.astm.org.

8. ASTM D2216-19, 2019. Standard Test Methods for Laboratory Determination of Water (Moisture) Content of Soil and Rock by Mass, ASTM International, West Conshohocken, PA, www.astm.org.

9. ASTM D2487-17e1, 2017. Standard Practice for Classification of Soils for Engineering Purposes (Unified Soil Classification System), ASTM International, West Conshohocken, PA, www.astm.org.

10. ASTM D422-63e2, 2007. Standard Test Method for Particle-Size Analysis of Soils (Withdrawn 2016), ASTM International, West Conshohocken, PA, www.astm.org.

11. ASTM D4318-17e1, 2017. Standard Test Methods for Liquid Limit, Plastic Limit, and Plasticity Index of Soils, ASTM International, West Conshohocken, PA, www.astm.org.

12. ASTM D698-12e2, 2012. Standard Test Methods for Laboratory Compaction Characteristics of Soil Using Standard Effort (12 $400 \mathrm{ft}-\mathrm{lbf} / \mathrm{ft} 3 \quad(600 \mathrm{kN}-\mathrm{m} / \mathrm{m} 3))$, ASTM International, West Conshohocken, PA, www.astm.org.

13. ASTM D1557-12e1, 2012. Standard Test Methods for Laboratory Compaction 
Characteristics of Soil Using Modified Effort $(56,000 \mathrm{ft}-\mathrm{lbf} / \mathrm{ft} 3 \quad(2,700 \mathrm{kN}-\mathrm{m} / \mathrm{m} 3))$, ASTM International, West Conshohocken, PA, www.astm.org.

14. ASTM D2435-03, 2003. Standard Test Methods for One-Dimensional Consolidation Properties of Soils Using Incremental Loading, ASTM International, West Conshohocken, PA, www.astm.org.

15. Casagrande, A., 1936. The Determination of the Pre-Consolidation Load and its Practical Significance, Proceedings of the First International Conference on Soil Mechanics and Foundation Engineering, pp60-64, 22-26 Haziran 1936, Cambridge.

16. KGM, 2013. Karayolu Teknik Şartnamesi, KGM Genel Müdürlüğü, Ankara.

17. DSİ, 1993. Barajlara ait Teknik Şartname, DSİ Genel Müdürlüğü, Ankara. 
